\title{
Occupational stress and self-perceived oral health in Brazilian adults: a Pro-Saude study
}

\author{
Estresse no trabalho e autopercepção de saúde oral \\ entre adultos brasileiros: Estudo Pró-Saúde
}

\author{
Giovana Pereira da Cunha Scalco \\ Claides Abegg ${ }^{1}$ \\ Roger Keller Celeste ${ }^{1}$ \\ Yara Hahr Marques Hökerberg ${ }^{2}$ \\ Eduardo Faerstein ${ }^{3}$
}

${ }^{1}$ Departamento de Odontologia Preventiva e Social, Faculdade de Odontologia, Universidade Federal do Rio Grande do Sul. R. Ramiro Barcelos 2492/3, Rio Branco. 90035-003 Porto Alegre RS.giscalco@hotmail.com ${ }^{2}$ Instituto de Pesquisa Clínica Evandro Chagas, Fundação Oswaldo Cruz. ${ }^{3}$ Departamento de Epidemiologia, Instituto de Medicina Social,

Universidade do Estado do Rio de Janeiro.

\begin{abstract}
The scope of this study is to investigate the association between occupational stress and self-perception of oral health. Data were obtained through a self-administered questionnaire filled out in a Pró-Saúde Study by 3253 administrative technical staff from Rio de Janeiro's State University. Occupational stress was measured by means of a questionnaire elaborated in 1970 by Karasek, duly shortened by Thorell in 1988. Ordinal logistic regression was used for data analysis, subsequently adjusted for three blocks of variables. Workers exposed to high occupational demands and little occupational control and to passive work had higher chances of self-perception of worse oral health, when compared with those exposed to low occupational demands, there being no association observed in those exposed to active work. However, in the multiple regression model the following estimates were reduced in magnitude and lost statistical significance, namely high occupational demands and passive work. Workers exposed to high occupational demands revealed worse self-reported oral health, which seems to be partly explained by health behavior patterns, the presence of oral health problems and seeking dental services at longer intervals than once per year. Key words Occupational stress, Self-perception of oral health, High occupational demands, Passive work, Oral health.
\end{abstract}

Resumo O objetivo deste estudo é investigar a associação entre estresse no trabalho e a autopercepção de saúde bucal. Os dados foram obtidos por meio de questionário de autopreenchimento de 3.253 funcionários técnicos administrativos da Universidade Estadual do Rio de Janeiro em um Estudo do Pró-Saúde. O estresse no trabalho foi medido por meio de um questionário elaborado por Karasek em 1970 e reduzido por Theorell em 1988. Para a análise dos dados, utilizou-se regressão logística ordinal, posteriormente ajustada para três blocos de variáveis. Trabalhadores expostos a alta exigência e pouco controle no trabalho e ao trabalho passivo, tiveram maiores chances de perceber pior saúde bucal, quando comparados àqueles expostos a baixa exigência no trabalho, não se observando associação com aqueles expostos ao trabalho ativo. Entretanto, no modelo de regressão múltipla, estas estimativas reduziram em magnitude e perderam significância estatística, a saber: alta exigência e trabalho passivo. Funcionários expostos à alta exigência no trabalho apresentaram pior saúde bucal autorreferida que parece ser em parte explicada pelas comportamentais em saúde, presença de problemas de saúde bucal e uso de serviços odontológicos com uma frequência maior do que uma vez ao ano.

Palavras-chave Estresse no trabalho, Autopercepção de saúde bucal, Alta exigência no trabatho, Trabalho passivo, Saúde bucal 


\section{Introduction}

Research has shown that work environment is one of the main causes of stress ${ }^{1}$. In addition, job stress has been the subject of several studies evaluating the relationship between psychosocial factors and health ${ }^{2}$. Stress, including job stress, can enhance the adoption of non healthy behaviors, such as worsening tooth brushing and smoking $^{3-5}$. Moreover, there is evidence suggesting that job stress is an important risk indicator for oral health outcomes ${ }^{6-9}$.

According to the Demand Control model (DC model), job strain occurs when workers are exposed simultaneously to high psychological demands and low decision latitude (control) at work $^{10}$. The Demand-Control-Support Questionnaire (17 items) is a modified version of the Job Content Questionnaire (49 items) ${ }^{11}$, which was adapted and validated for the Brazilian culture $^{12,13}$. The Karasek's quadrant classified workers in four categories: 1) high job strain - a combination of high demands and low control, hypothesized to increase the risk of stress-related illness; 2) passive job - low demands and control; 3 ) active job - high demands and control; 4) low strain - low demands and high control.

Few studies have investigated the association between job stress and oral health using the demand control instrument $t^{4,14,15}$. One of the first investigations found a positive association between job stress and periodontal disease ${ }^{15}$. Another study has demonstrated that individuals with more flexibility in their working time schedule have higher frequency and better quality of tooth brushing compared to those with less flexibility ${ }^{4}$. More recently, Söderfeldt et al. found an association between job stress and self-perceived oral health ${ }^{15}$. In all studies, only some dimensions of job stress were explored, and the influence of social support at work on oral health has not been described. Research using the four Karasek's quadrants of the original scale has not been investigated, which could be important to support these studies.

There is evidence of a relationship between job stress and self-perceived (general) health ${ }^{16}$. It may be argued that this association could also be observed in relation to oral health, since job stress favors the adoption of unhealthy behaviors that can worsen one's perception of oral health ${ }^{3-5}$. Studies are needed to confirm the existence of this association and to elucidate its possible mechanisms in order to build strategies for reducing the impact of stress in the workplace. Therefore, the aim of the present study is to investigate the relationship between job stress and self-perceived oral health among university public servers.

\section{Methods}

This is a cross-sectional study using the baseline (1999-2001) data from the cohort Pró-Saúde Study ${ }^{17}$. The study participants were all nonfaculty civil servants, employees of the University of the Rio de Janeiro State. All employees were considered eligible, excluding those on a temporary basis, transferred, inactive or on sick/maternal leave. A total number of 3253 employees participated in both years, providing baseline data ${ }^{17}$. Data were collected in the workplace through a self-administered questionnaire. Regarding the ethical aspects, the study was approved by the Ethics Committee in Research of Hospital Universitário Pedro Ernesto within the standards required by Declaration of Helsinki.

\section{Independent Variables}

Job stress was measured using the DemandControl-Support Questionnaire (DCSQ) proposed by Theorell in 1988 and adapted to the Brazilian Portuguese $^{12}$. The DCSQ has 17 items distributed in 3 subscales: psychological demands (5 items), control (6 items) and social support at work (6 items). The score of the first two subscales is the sum of the item scores, based on four answer options ranging from 'often' (4 points) to 'never/almost never' ( 1 point). The scores were dichotomized at the median (demand $<15$ and control $<17$ ) as proposed by Macedo et al. ${ }^{18}$. Subjects were classified according to the Karasek quadrants: 1) high strain (high demand and low control), 2) passive job (low levels of demand and control), 3 ) active job (high demand and control) and 4) low strain (low demand and high control), the reference category.

\section{Dependent Variable}

The outcome studied is self-perceived oral health. This variable was collected by the question: "In general, as you consider your state of oral health (teeth and gums)? It has four options ranging from "very good" to "very bad", with scores ranging from 1 to 4 , respectively ${ }^{19}$. 


\section{Covariates}

Three blocks of covariates were considered. The first included socio-demographic variables, considered potential confounding factors: age in years, sex (male/female), household income was equivalized using the square root of the number of residents, then converted to minimum wages, and education (University degree or more/complete high school/less than high school). The second block included distal mediator variables: smoking (never smoker/ex-smoker/smokers), self-perceived general health (4 options from "very good" to "very bad"), and the DCSQ subscale of social support at work that was dichotomized at the median $(<20)$. The third block consisted of proximal mediators: self-reported tooth loss (4 answer options ranging from "none" to "all or almost all"), dental pain in the last two weeks (yes/ no) and frequency of dental visit (once a year/ every two years or more/only when in trouble).

\section{Statistical Analysis}

Bivariate analysis results were presented in a contingency table and the chi-square test were used to evaluate the association between job strain and self-perceived oral health. Multivariate analyses were carried out fitting ordinal logistic regression with partial proportional models according to Hosmer and Lemeshow ${ }^{20}$. The Brand test for all covariates ( $\alpha$ was set to $1 \%$ significance) was used to assess the proportional odds assumption. When any variable violated the proportional odds assumption it was used partial proportional models. This assumption was not violated by the job strain variable in any model.

To evaluate the impact of a set of similar variables, maybe collinear, we built one model for every block of similar variables previously described. For the final model only those variables with $\mathrm{p}<0.20$ within each previous model were retained. The main exposure variable was included in all statistical models. Model fit was evaluated through two main parameters: Bayesian Information Criteria and adjusted pseudo- $\mathrm{R}^{2}$. The best (final) model was also assessing with goodness-of-fit test as described elsewhere ${ }^{20}$. All analyses were performed using Stata 11.2.

\section{Results}

Among the 3253 technical-administrative employees who participated in the two phases, 2770 were included in the final analysis $(15.1 \%$ missing). Of these, $44.1 \%$ were male and the mean age was 42.5 years. Regarding socioeconomic status, average equivalized household income was 7.4 minimum wages $(\mathrm{R} \$ 1,316.29)$ and $42.1 \%$ of employees had completed the university degree or more. Only $8.0 \%$ of the participants reported having lost all or almost all teeth, $2.8 \%$ had dental pain in the last two weeks, and $62 \%$ perceived their oral health as good or very good. With regard to job stress, $33.9 \%$ were classified as low strain (low demands / high control) and 14.5\% as high strain (high demands / low control).

The association between job strain and selfperceived oral health was statistically significant $(\mathrm{p}<0.01)$. In the high strain group, $11.9 \%$ perceived their oral health as very good and $1.9 \%$ as very bad, as compared to the low strain group, where $18.9 \%$ of subjects self-rated their oral health as very good and $0.6 \%$ as very poor ( $\mathrm{Ta}-$ ble 1).

In ordinal logistic regression crude analysis, compared to low strain group, employees exposed to passive and high strain jobs were more likely to be at the worse category of self-perceived oral health, with proportional odds ratio of 1.35 (95\% CI: 1.14 to 1.59 ) and 1.66 (95\% CI: 1.38 to $2.03)$, respectively. The magnitude of these estimates decreased when we adjusted for each block of variables (models M2 to M4, Table 2). Each block of variables contributed similarly to the reduction of the magnitude of the effect of job stress on self-perceived oral health. However, in the final model, these estimates lost statistical significance, with a proportion odds ratio of 1.10 (95\% CI: 0.92 to 1.33 ) and 1.18 (95\% CI: 0.94 to 1.49), respectively for passive and high strain jobs (model M5, Table 2). The variables that remained associated with worse self-perceived oral health were (Table 3): tooth loss, dental visits, dental pain, worse self-rated general health, smoking, education, income and age.

The final (fully adjusted) model presented the best fit (pseudo- $\mathrm{R}^{2}=14.3 \%$; AIC $=2.16$ ), followed by the block of proximal variables - oral health and dental visits (pseudo- $\mathrm{R}^{2}=9.2 \%$; $\mathrm{AIC}=2.27$ ), the second block of distal variables (pseudo- $\mathrm{R}^{2}=$ $6.1 \%$; AIC $=2.36$ ) and finally by the socio-demographic factors (pseudo- $\mathrm{R}^{2}=5.8 \%$; AIC $=2.37$ ). 
Table 1. Distribution of workers according to job strain and self-perceived oral health.

\begin{tabular}{ccrrrrrr}
\hline & & \multicolumn{7}{c}{ Self-perceived Oral Health } \\
\cline { 2 - 7 } Job Strain & \multicolumn{1}{c}{$\begin{array}{c}\text { Very } \\
\text { Good }\end{array}$} & Good & Regular & Bad & $\begin{array}{r}\text { Very } \\
\text { Bad }\end{array}$ & Total \\
\hline Low Strain: & $\mathrm{n}$ & 205 & 506 & 308 & 61 & 6 & 1086 \\
High Control/Low Demand & $(\%)$ & $(18.9)$ & $(46.6)$ & $(88.4)$ & $(5.6)$ & $(0.6)$ & $(100)$ \\
Passive Work: & $\mathrm{n}$ & 135 & 347 & 268 & 69 & 12 & 831 \\
Low Control/Low Demand & $(\%)$ & $(16.3)$ & $(41.8)$ & $(32.2)$ & $(8.3)$ & $(1.4)$ & $(100)$ \\
Active Work: & $\mathrm{n}$ & 144 & 400 & 235 & 48 & 2 & 829 \\
High Control/High Demand & $(\%)$ & $(17.4)$ & $(48.2)$ & $(28.4)$ & $(5.8)$ & $(0.2)$ & $(100)$ \\
High Strain: & $\mathrm{n}$ & 55 & 198 & 157 & 45 & 9 & 464 \\
Low Control/High Demand & $(\%)$ & $(11.9)$ & $(42.7)$ & $(33.8)$ & $(9.7)$ & $(1.9)$ & $(100)$ \\
Total & $\mathrm{n}$ & 539 & 1451 & 968 & 223 & 29 & 3210 \\
& $(\%)$ & $(16.7)$ & $(45.1)$ & $(30.3)$ & $(7.0)$ & $(0.9)$ & $(100)$ \\
& & & & & &
\end{tabular}

Note: chi-square test p-value $<0.001$

Table 2. Proportional odds ratio, with 95\% Confidence Interval (95\% CI), of being in a worse category of self-perceived oral health according to each job strain category in crude and adjusted ordinal logistic regression models.

\begin{tabular}{lccccc}
\hline & & \multicolumn{2}{c}{ Proportional Odds Ratio (95\% CI) } \\
\cline { 3 - 6 } \multicolumn{1}{c}{ Model } & Low Strain & Passive Work & Active Work & High Strain \\
\hline M1: Crude model & 1 & $1.35(1.14-1.59)$ & $1.03(0.86 .-1.21)$ & $1.66(1.38-2.03)$ \\
M2: Socio-demografic variables & 1 & $1.20(1.01-1.43)$ & $1.14(0.96-1.36)$ & $1.40(1.13-1.73)$ \\
M3: Other distal variables & 1 & $1.29(1.08-1.53)$ & $1.00(0.84 .-1.20$ & $1.37(1.10-1.70)$ \\
M4: Oral health and health services & 1 & $1.19(1.00-1.42)$ & $1.06(0.89-1.26)$ & $1.59(1.29-1.96)$ \\
M5: Fully adjusted model & 1 & $1.10(0.92-1.33)$ & $1.07(0.89-1.30)$ & $1.18(0.94-1.49)$ \\
\hline
\end{tabular}

$\mathrm{M} 1=$ job strain (Karasek's quadrant categories). M2 = M1+ age, sex, income and education. M3 = M1+ smoking, self-perceived general health and social support at work. M4 = M1+ dental pain, tooth loss, dental visits. M5 = M1+ age, income, education, smoking, self-perceived general health, dental pain, tooth loss, dental visits.

\section{Discussion}

In this study, we found that workers simultaneously exposed to high job demands and low control at work seemed to have worse self-perceived oral health than those exposed to low job demands and high control at work. However, the magnitude of this estimate decreased after adjusting for three groups of variables (socio-demographic and other distal variables, and oral health/dental services) and lost statistical significance in the final (fully adjusted) model. The association between job stress and self-perceived oral health was confirmed by Söderfeldt et al. ${ }^{15}$. This study has found that individuals exposed to higher levels of job stress reported worse selfrated oral health.

In addition, the relationship between job stress and self-perceived general health has been investigated in other studies ${ }^{16,21,22}$. Authors who used some dimensions of the job stress scale have found a consistent association between job control and self-rated health ${ }^{16,22}$. In one study, those who had high psychological demands at work reported worse self-rated health ${ }^{22}$.

It is possible that in the present study, the variables smoking, self-rated general health, use of dental services, dental pain and tooth loss have mediated the relationship between job strain and self-perceived oral health. There is a strong evidence supporting the relationship between job stress and health risk behaviors such as smoking and low frequency of toothbrushing ${ }^{4,23}$. Distress may occur when individual's coping resources are not enough to deal with stressful stimulus ${ }^{24}$, favoring the adoption of unhealthy behaviors. At least one study reported that workers with less flexible work schedules presented lower fre- 
Table 3. Proportional odds ratio (POR), with 95\% Confidence Interval (95\% CI), of being in a worse category of self-perceived oral health in ordinal logistic regression in the final (fully adjusted) model.

\begin{tabular}{|c|c|c|c|}
\hline & \multicolumn{3}{|c|}{ Self-perceived Oral Health } \\
\hline & & POR & $95 \% \mathrm{CI}$ \\
\hline \multirow[t]{4}{*}{ Job Strain } & Low Strain & 1 & \\
\hline & Passive & 1.10 & $(0.92-1.33)$ \\
\hline & Active & 1.07 & $(0.89-1.30)$ \\
\hline & High Strain & 1.18 & $(0.94-1.49)$ \\
\hline \multirow[t]{4}{*}{ Tooth Loss } & None & 1 & \\
\hline & One or few & 2.42 & $(1.99-2.96)$ \\
\hline & Many & 6.48 & $(4.94-8.49)$ \\
\hline & Almost all or all & 4.70 & $(3.24-6.82)$ \\
\hline \multirow[t]{3}{*}{ Dental Visits } & Once a year & 1 & \\
\hline & Every two year or more & 1.64 & $(1.36-1.98)$ \\
\hline & Only in trouble & 2.65 & $(2.23-3.16)$ \\
\hline \multirow[t]{2}{*}{ Dental Pain in the last two weeks } & No & 1 & \\
\hline & Yes & 2.25 & $(1.46-3.49)$ \\
\hline \multirow[t]{2}{*}{ Social Support at Work } & $<20$ & 1 & \\
\hline & $\geq 20$ & 0.98 & $(0.85-1.14)$ \\
\hline \multirow[t]{3}{*}{ Smoking } & Never smoker & 1 & \\
\hline & Ex-smoker & 1.16 & $(0.96-1.40)$ \\
\hline & Smoker & 1.51 & $(1.26-1.82)$ \\
\hline \multirow[t]{4}{*}{ Self-perceived (general) health } & Very good & 1 & \\
\hline & Good & 2.50 & $(2.10-2.96)$ \\
\hline & Regular & 4.84 & $(3.83-6.11)$ \\
\hline & Bad & 4.37 & $(2.38-8.09)$ \\
\hline \multirow[t]{3}{*}{ Education } & University or more & 1 & \\
\hline & High School & 1.23 & $(1.03-1.46)$ \\
\hline & Less Than High School & 1.19 & $(0.93-1.51)$ \\
\hline Age (years) & & $0,99^{*}$ & $(0.98-1.00)$ \\
\hline Equivalized household income & Minimum Wages & $0.95^{* *}$ & $(0.94-0.97)$ \\
\hline
\end{tabular}

"Referent to an increase of one year. ${ }^{* *}$ Referent to an increase of one equivalent minimum wage.

quency of tooth cleaning than those with high flexible schedules ${ }^{4}$. Smoking and poor tooth brushing are risk factors for periodontal disease and together can increase the risk of tooth loss ${ }^{23}$. Studies have shown that tooth loss is one of the most influential variables that explain self-perceived oral health ${ }^{19,25}$.

The strengths of this study include the large sample size and the use of cross-cultural adapted and validated measurement instruments ${ }^{12,13,17,26}$. However, there are some limitations. First, the response rate was $84.9 \%$, but we do not believe that it would modify our results, giving the high number of subjects participating in the study. Second, the direction of the association between job strain and self-perceived oral health cannot be determined due to the cross-sectional design. Thirdly, we cannot rule out the presence of overlap between the perception of general health and oral health. The perception of general health influences the perception of oral health. Thus, peo- ple who have poor oral health may not perceive it as poor general health. The opposite can also happen, those workers who have had their general health compromised may underestimate the problems of oral health.

Studies such as the present are relevant as they explore individual and subjective health indicators which should be taken into consideration when measuring health conditions. Therefore, they not rely only on normative judgment, which is a limited and insufficient measure. Finally, further research with longitudinal design will be necessary to establish the causal relationships and to confirm the findings of the present study.

\section{Collaborators}

GPC Scalco, C Abegg, RK Celeste, YHM Hökerberg e E Faerstein participated equally in all stages of preparation of the article. 


\section{References}

1. Stansfeld S, Head J, Marmot M. Work related factor and ill health. The WhitehaII Study. Norwich: Health \& Safety Executive; 2000.

2. Kivimaki M, Leino-Arjas P, Luukkonen R, Riihimaki H, Vahtera J, Kirjonen J. Work stress and risk of cardiovascular morbidity: prospective cohort study of industrial employees. BMJ 2002; 325(7369):857.

3. Pickering TG. The effects of environmental and lifestyle factors on blood pressure and the intermediary role of the sympathetic nervous system. J Hum Hypertens 1997; 11(Supl.):S9-S18.

4. Abegg C, Marcenes W, Croucher R, Sheiham A. The relationship between tooth cleaning behaviour and flexibility of working time schedule. J Clin Periodontol 1999; 26(7):448-452.

5. Matthews KA, Gallo LC, Taylor SE. Are psychosocial factors mediators of socioeconomic status and health connections? A progress report and blueprint for the future. Ann N Y Acad Sci 2010; 1186:146-173.

6. da Silva SR, Castellanos Fernandes RA. Self-perception of oral health status by the elderly. Rev Saude Publica 2001; 35(4):349-355.

7. Breivik T, Thrane PS, Murison R, Gjermo P. Emotional stress effects on immunity, gingivitis and periodontitis. Eur J Oral Sci 1996; 104(4[Pt. 1]):327-334.

8. Aurer A, Aurer-Kozelj J, Stavljenic-Rukavina A, Kalenic S, Ivic-Kardum M, Haban V. Inflammatory mediators in saliva of patients with rapidly progressive periodontitis during war stress induced incidence increase. Coll Antropol 1999; 23(1):117-124.

9. Genco RJ, Ho AW, Grossi SG, Dunford RG, Tedesco LA. Relationship of stress, distress and inadequate coping behaviors to periodontal disease. $J$ Periodontol 1999; 70(7):711-723.

10. Karasek RA. Job demands, job decision latitude, and mental strain: implications for job redesign. Adm Sci Q 1979; 24(2):285-307.

11. Theorell T. The Demand-Control-Support model for studying health in relation to the work environment: an interactive model. In: Orth-Gomér K, Schneiderman N, editors. Behavioral medicine approaches to cardiovascular disease prevention. Mahwah: Lawrence Erlbaum Associates INC. Publishers; 1996. p. 69-85.

12. Alves MG, Chor D, Faerstein E, Lopes Cde S, Werneck GL. Short version of the "job stress scale": a Portuguese-language adaptation. Rev Saude Publica 2004; 38(2):164-171.

13. Hokerberg YH, Aguiar OB, Reichenheim M, Faerstein E, Valente JG, Fonseca Mde J, Passos SR. Dimensional structure of the demand control support questionnaire: a Brazilian context. Int Arch Occup Environ Health 2010; 83(4):407-416.

14. Marcenes WS, Sheiham A. The relationship be tween work stress and oral health status. Soc Sci Med 1992; 35(12):1511-1520.

15. Söderfeldt M, Axtelius B, Soderfeldt B, Unell L. Demand and control in human service work in relation to self-rated oral health. Community Dent Health 2002; 19(3):180-185.
16. Borg V, Kristensen TS. Social class and self-rated health: can the gradient be explained by differences in life style or work environment? Soc Sci Med 2000; 51(7):1019-1030.

17. Faerstein E, Chor D, Lopes CS, Werneck GL. The Pro-Saude Study: general characteristics and methodological aspects. Rev Bras Epidemiol 2005; 8(4): 454-466.

18. Macedo LE, Chor D, Andreozzi V, Faerstein E, Werneck GL, Lopes CS. Job stress and interruption of routine activities due to health problems, according to the Pro-Saude Study. Cad Saude Publica 2007; 23(10):2327-2336

19. Afonso-Souza G, Nadanovsky P, Chor D, Faerstein E, Werneck GL, Lopes CS. Association between routine visits for dental checkup and self-perceived oral health in an adult population in Rio de Janeiro: the Pro-Saude Study. Community Dent Oral Epidemiol 2007; 35(5):393-400.

20. Hosmer DW, Lemeshow S. Applied logistic regression. $2^{\text {nd }}$ Edition. New York: Wiley; 2000.

21. Ibrahim SA, Scott FE, Cole DC, Shannon HS, Eyles J. Job strain and self-reported health among working women and men: an analysis of the 1994/5 Canadian National Population Health Survey. Women Health 2001; 33(1-2):105-124

22. Pikhart H, Bobak M, Siegrist J, Pajak A, Rywik S, Kyshegyi J, Gostautas A, Skodova Z, Marmot M. Psychosocial work characteristics and self rated health in four post-communist countries. J Epidemiol Community Health 2001; 55(9):624-630.

23. Thomson WM, Poulton R, Milne BJ, Caspi A, Broughton JR, Ayers KM. Socioeconomic inequalities in oral health in childhood and adulthood in a birth cohort. Community Dent Oral Epidemiol 2004; 32(5):345-353.

24. Sanders AE, Slade GD, Turrel G, Spencer AJ, Marcenes W. Does Psychological Stress Mediate Social Deprivation in Tooth Loss. J Dent Res 2007; 86(12): 1166-1170.

25. Pattussi MP, Olinto MT, Hardy R, Sheiham A. Clinical, social and psychosocial factors associated with self-rated oral health in Brazilian adolescents. Community Dent Oral Epidemiol 2007; 35(5):377-386.

26. Afonso-Souza G, Nadanovsky P, Werneck GL, Faerstein E, Chor D, Lopes CS. Test-retest reliability of self-perceived oral health in an adult population in Rio de Janeiro, Brazil. Cad Saude Publica 2007; 23(6):1483-1488.

Artigo apresentado em 10/08/2012

Aprovado em 22/09/2012

Versão final apresentada em 15/10/2012 